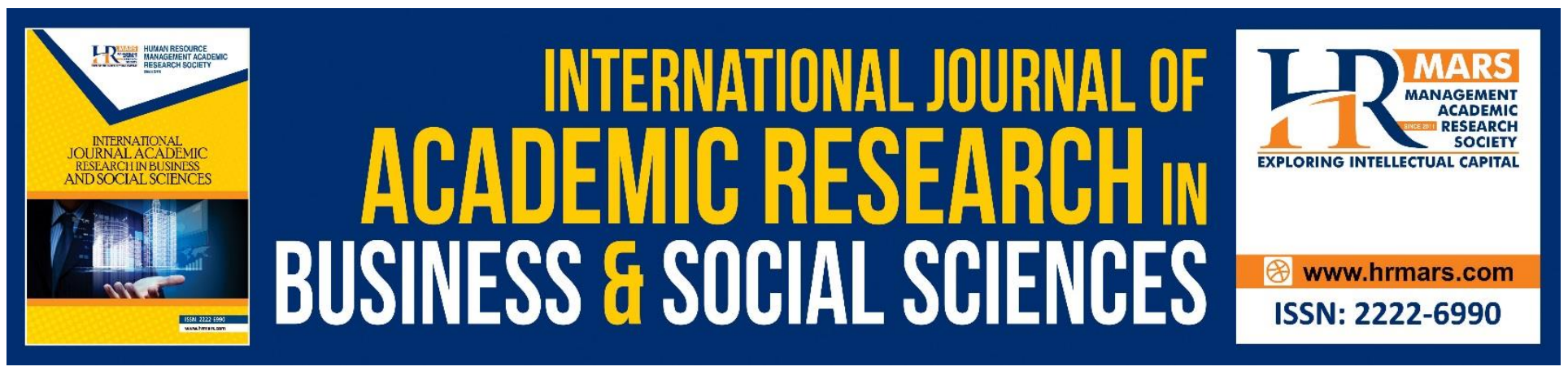

\title{
Distributive and Procedural Justice, Perceived Organizational Support, and Its Effect on Organizational Commitment in Public Organization
}

Joni Dawud, Hafid Aditya Pradesa, Muhamad Nur Afandi

To Link this Article: http://dx.doi.org/10.6007/IJARBSS/v8-i12/5189

DOI: $10.6007 /$ IJARBSS/v8-i12/5189

Received: 11 Nov 2018, Revised: 21 Dec 2018, Accepted: 27 Dec 2018

Published Online: 05 Jan 2018

In-Text Citation: (Dawud, Pradesa, \& Afandi, 2018)

To Cite this Article: Dawud, J., Pradesa, H. A., \& Afandi, M. N. (2018). Distributive and Procedural Justice, Perceived Organizational Support, and Its Effect on Organizational Commitment in Public Organization. International Journal of Academic Research in Business and Social Sciences, 8(12), 1675-1188.

Copyright: (C) 2018 The Author(s)

Published by Human Resource Management Academic Research Society (www.hrmars.com)

This article is published under the Creative Commons Attribution (CC BY 4.0) license. Anyone may reproduce, distribute, translate and create derivative works of this article (for both commercial and non-commercial purposes), subject to full attribution to the original publication and authors. The full terms of this license may be seen at: http://creativecommons.org/licences/by/4.0/legalcode

Vol. 8, No. 12, 2018, Pg. 1675 - 1188

Full Terms \& Conditions of access and use can be found at http://hrmars.com/index.php/pages/detail/publication-ethics 


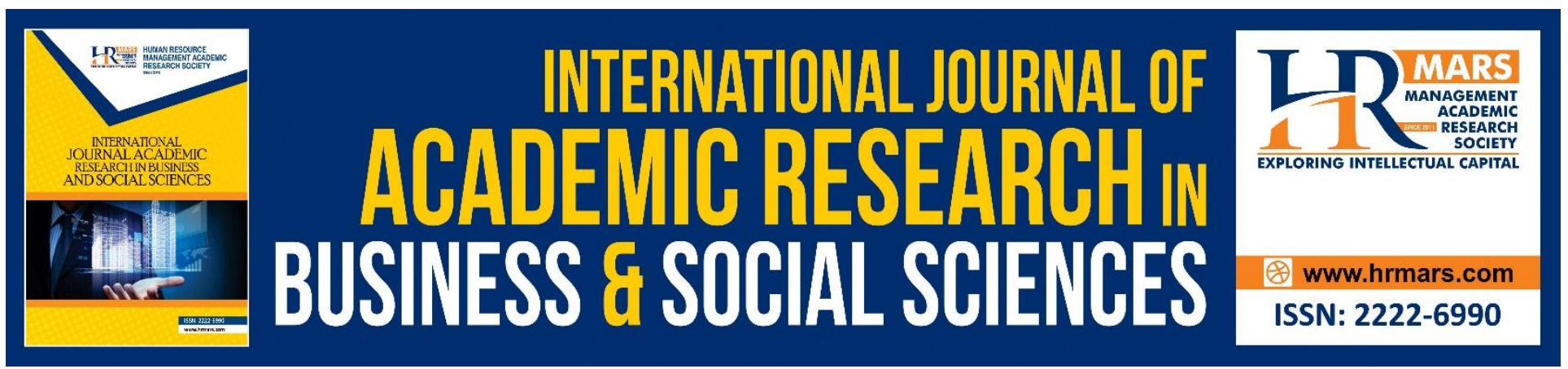

\title{
Distributive and Procedural Justice, Perceived Organizational Support, and Its Effect on Organizational Commitment in Public Organization
}

\author{
Joni Dawud, Hafid Aditya Pradesa, Muhamad Nur Afandi
}

School of Administration, National Agency for State Administration, Bandung, West Java, Indonesia

Abstract: Social exchange theory generally exists in every part of social construction in civil society. Organizational justice, organizational support, and affective commitment could be built and examined in conceptual framework based on social exchange theory perspective. Perceived organizational support (POS) involves employees' general perception about organization in valuing of their contributions and cares about their well-being. POS has been found to be the work experience which is most strongly linked to the commitment to the organization (organizational commitment). Furthermore, distributive and procedural justice would be treated as the antecedent of POS and commitment. Hypotheses proposed in this study argued that organizational support is more important as part of social exchange processes in public organization than the presumption that individual and organization are separate entities psychologically and more closely aligned with job attitude toward organization. As a cross-sectional design, quota sampling is used in this study. Data was collected from 42 civil servant officers in West Java Province. Partial-Least Square Structural Equation Modeling (PLS-SEM Based) is used to analyze data collected from survey. Result indicated that procedural justice and POS were significantly related to organizational commitment. Contrary to expectation, distributive justice was not significantly related to organizational commitment. Also, the study highlights the greatest effect founded in the relationship between POS and organizational commitment. These results suggest that in order to enhance commitment among civil servant officers, public organization must enforce greater effect of fair treatment by ensuring support for them. Implications and directions for future research are also discussed.

Keywords : Distributive Justice, Procedural Justice, Perceived Organizational Support, Organizational Commitment.

Introduction

Concept of organizational commitment is commonly examined in many previous researches. Thus, many researchers have dedicated several years to this topic in various field of study. Compared to the private sector, human resource management (HRM) practices in the public sector tends to be 
INTERNATIONAL JOURNAL OF ACADEMIC RESEARCH IN BUSINESS AND SOCIAL SCIENCES Vol. 8, No. 12, Dec, 2018, E-ISSN: 2222-6990 @ 2018 HRMARS

more concerned about increasing well-being at workplace than fostering effectiveness (Boyne, Poole and Jenkins, 1999).

While taking issue about commitment, researcher must notice the importance of having concern to commitment that induce objective responses at the correct level-of-analysis and also about locus of the study. Gaining a better understanding of the factors related with organizational commitment among public officers is important for public administrator in order to shape management decisions, improve officer performance. Thus, officers who are committed to their organization are likely to make better public officers.

Although the importance of organizational commitment and its role in improving various organizational outputs and outcomes, as well as the attention co-exist in the private sector literature, exploratory study of commitment in public organization still remains stuck. Somewhat the public management literature is silent about the justice factors that generate greater levels of commitment (Moldogaziev and Silvia, 2015).Commitment among public employees is usually strengthened by leadership (Moldogaziev and Silvia, 2015; Kim, 2013).

Miao et al.,(2014) argued that organizational commitment has been studied by many previous researchers in public administration as it relates to various positive attitudinal antecedents and consequences. Nonetheless, one of the organizational problem arise is a lack of commitment to the organization, such as in police institution (Crow et al., 2012) which could have cascading effects, especially among experienced officers who often shape the attitudes and experiences of new recruits through the socialization process.

Paille, Grima, and Dufour (2015) argued that SET remains largely unused in the field of public sector of HRM and governed by a series of codified rules and social practices designed to instill a positive 'atmosphere'. Furthermore, an analysis based on SET may be useful for understanding employer-employee relationship in the context of the public sector. Yet, despite the greater concern of organizational commitment among public officers, it is relatively little known about the attitudinal mechanism processes that influence organizational commitment, which especially based on social exchange perspective in officers' perception of organizational justice.

However, no previous empirical studies have assessed the link between these social exchange mechanisms of perceived organizational and commitment to the public organization. To address this gap, we build on these previous studies which focus explicitly on the part that organizational justice in fostering commitment to the organization through perceived organizational support.

Organizational commitment is particularly relevant in the Indonesian public sector, which continues to undergo fundamental change through attempts to improve administrative capacity. Over the past few years, The Indonesian government authority has increasingly called for more 'service-oriented' administrative, emphasized the need for every government officials in all institution from act selflessly to best serve society. Essentially, this was a call for more building commitment among public officers, and our study investigates how public-sector employees of West Java Province respond to this.

Paille et al. (2015) argued that many previous studies have examined the employment relation, with some studies have focused more specifically on employees in the public sector. Because of its specific object, this study would add the literature of public sector. This article makes two main contributions to the existing literature. First, it examines whether social exchange mechanism can be 
used to promote positive attitudes (such as commitment) among public sector employees toward organization. This is because of the fact that previous studies only have highlighted the importance of supportive managerial practices related with organizational commitment in public sector organizations (Steijn and Leisink 2006; Dick 2011).

This paper also explores how social exchange theory is applicable in fostering public officers' commitment. We argue, however, that public employees also have experience in social exchange mechanism. The approach applied in this study is by examined commitment in organizational-level at public organization, with social exchange context.

According to the present study, we argue that there is a strong mediating role of perceived organizational support in the relationship of distributive and procedural justice on public officers' organizational commitment. By using structural equation modeling for any possible indirect relationship between the latent variables, the current study seeks to contribute to the literature by exploring the relationship between organizational justice, support and commitment. Whereas previous studies have examined the linear relationship among these variables, this study attempts to uncover more complex relationships by utilizing structural models.

\section{Literature Review and Hypotheses Organizational Justice and POS}

As a theoretical concept has regarded how people are treated within an organization, organizational justice is usually divided into two main dimensions: distributive and procedural justice (Muchinsky, 2008; Colquitt, 2001). Distributive justice is defined as the fairness related to the distributional outcomes to the organizational members (Jones, 1998). The existence of distributive justice is related with outcomes such as compensation, benefits, and other rewards which meet employees' expectations in relation to their inputs (Chou, 2009; Clay-Warner et al., 2005). In aside, organizational support theory (OST) suggests that employees sometimes ascribe human like attributes to their organizations, in which organizational actions taken by its agents such as managers are viewed as the organizations' intentions (Aselage \& Eisenberger, 2003; Rhoades \& Eisenberger, 2002).

Many previous research studies concerning the effect of justice on attitudinal variables such as job satisfaction and organizational commitment (Colquitt, 2001), and suggests that perception of organizational justice is correlated with spesific organizational factors, including perceived organizational support (Rhoades and Eisenberger ,2002).As Virgolino et al., (2017) stated that perception of justice is an important factor that could affecting their judgements about their organizations. In other words, officers are more likely to feel that outcomes are fair if they acknowledge the process and their supervisors are fair. This is built from social exchange theory in order to explain the relationship between justice and organizational support. Therefore, the following hypothesis is proposed:

H1. Distributive justice will have a positive and significant effect on public officers' perceived organizational support.

H2. Procedural justice will have a positive and significant effect on public officers' perceived organizational support. 
INTERNATIONAL JOURNAL OF ACADEMIC RESEARCH IN BUSINESS AND SOCIAL SCIENCES

Vol. 8, No. 12, Dec, 2018, E-ISSN: 2222-6990 @ 2018 HRMARS

\section{Organizational Justice and Commitment}

As a psychological attachment of an individual to an organization exist, organizational commitment is usually defined and presented by different indicators, such as affective, normative, and continuance commitment. Allen and Meyer (1990) developed these concepts by providing a three-dimensional model of organizational commitment. Furthermore, they have attempted to provide a comprehensive model from three perspectives.

Organizational justice needs to be examined in public officers for its relationship with other organizational behaviors (e.g. organizational commitment). From some previous studies that have tested organizational commitment, independent variables have been retrieved mostly from the organizational dimension, such as organizational support (Currie and Dollery, 2006; Rhoades and Eisenberger, 2002). In the situation of high distributive and procedural justice, officers should also increase their commitment to organization. Crawshaw (2006) argued that fairness perceptions will not only relate to fringe benefits but also to other specific situations such as access to developmental opportunities. Prior research has conceptualized all organizational justice variables as having independent effects on organizational commitment (Crow et al., 2012; Lambert, Hogan, and Griffin, 2007). Thus, it is required to investigate the potential complex relationships among organizational justice and organizational commitment in the public organization literature. Accordingly, the following hypothesis is proposed.

H3. Distributive justice will have a positive and significant effect on public officers' organizational commitment.

H4. Procedural justice will have a positive and significant effect on public officers' organizational commitment.

\section{POS and Commitment}

Consistent with the social exchange framework, Cropanzano and Mitchell (2005) showed that POS will plays important role in building employee's commitment. POS refers to the individual's belief that the organization values will have contributions made by the employee (Rhoades and Eisenberger, 2002; Eisenberger et al., 1986), and shows great concern for the well-being of employees at work (Eisenberger, Fasolo and Davis-LaMastro, 1990). As its consistent with relational models of social exchange theory or SET (Cropanzano and Mitchell, 2005), there have been positive relationships between POS and employee commitment (Rhoades and Eisenberger, 2002). Paille et al., (2015) argued that the relationship between POS and employee commitment is well documented in the private sector, but in contrary there are very limited number of research which have been conducted among employees working in the public sector.

Moreover, public officers often exhibit greater commitment to their job or supervisor than to organization. It is believed that employees are more committed to the organization if they perceive that their employer shows greater and positive concern about employees' wellbeing. Thus, it can be seen that the perception of public officers' perceived organizational support should have a greater effect on organizational commitment. Therefore, the following hypothesis is proposed:

H5. Perceived organizational support will have a positive and significant effect on public officers' organizational commitment. 


\section{Mediating role of POS}

One of the primary goals of this study is to examine perceived organizational support as a boundary condition that may affect the strength of the relationship between justice and commitment. As POS would be influenced by various aspects of an employee's interpretation underlying treatment from organization, it also could influence another attitudinal or behavioral mechanism whether directly or not. However, to explain why organizational justice may affect organizational positive outcomes (OCB, commitment, low turnover) through perceived organizational support, we proposed this schematic relationship that based on Shore and Shore (1995) in which their arguments show mediating role of POS in how perceptions of justice create a "global schema of history of support" that is more likely to impact employee attitudes and behavior via fair treatment. Therefore, we focus on distributive justice, which is defined as perceived fairness of an employee's rewards and outcomes compared to his or her efforts and inputs (Colquitt, 2001) and procedural justice, which is focuses on the process that leads to the results (Cropanzano and Greenberg, 1997).These two are seen as the key drivers of work-related attitudes and behaviors such as commitment (Colquitt et al., 2001).Specifically, the hypotheses in the current study are proposed below:

H6. Perceived organizational support will have a positive and significant mediating effect on the effect of distributive justice toward public officers' organizational commitment.

H7. Perceived organizational support has a significant mediating role in the effect of procedural justice on public officers' organizational commitment.

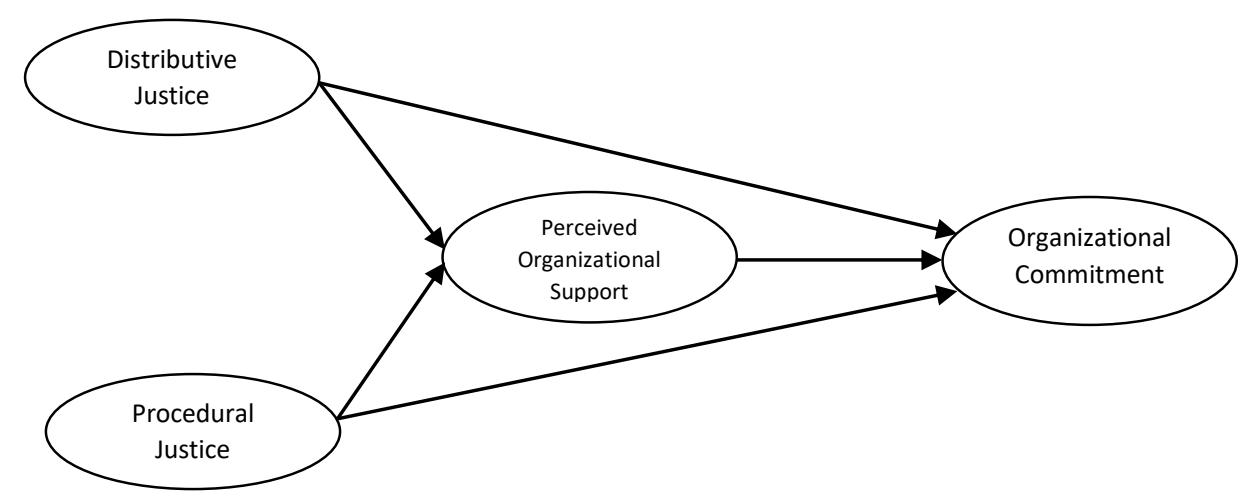

Figure 1. Conceptual Framework

The relationship depicted above is represented through a direct effect model. Based on the previous findings and theoretical described previously, we expect that potential mediating role of perceived organizational support could predict the effect of distributive and procedural justice on organizational commitment.

\section{Method}

\section{Context and Participants}

The respondents of this study were public officers employed in the West Java Province, a regional government organization. The participants were representative of the departmental office for the 
INTERNATIONAL JOURNAL OF ACADEMIC RESEARCH IN BUSINESS AND SOCIAL SCIENCES Vol. 8, No. 12, Dec, 2018, E-ISSN: 2222-6990 @ 2018 HRMARS

regional government agencies, as many as 42 officers were taken as respondent in this study. Since operationalization of variables and corresponding questions were adopted from different researchers in previous studies, all the respondents were educated and could fill the questionnaire with complete understanding of questions. Based on theoretical and empirical support from previous researches, close ended questionnaires were built and used to test the hypotheses.

\section{Measurement}

A questionnaire survey was used to obtain measures of distributive and procedural justice, perceived organizational support, and organizational commitment. The survey instrument used in this study contains four established instruments. These are distributive and procedural justice questionnaire (adopted from Niehoff and Moorman, 1993; and Colquitt, 2001), Perceived organizational support (POS) questionnaire (adopted from Eisenberger et al.,1986), and organizational commitment questionnaire (OCQ) adopted from Allen and Meyer (1990). Scores obtained from these instruments were used to define variables listed in Table 1. Each of the questions used to construct these variables asked the respondent to either rate their perceptions of various conditions and processes. Finally, based on a Likert-type scale, all items used in this study were measured on a 5-point scale ranging from 1 (completely disagree) to 5 (completely agree).

\section{Analysis}

The current study addresses these limitations by using a sample of public officers and by employing Partial least squares (PLS)-based structural equation modeling to better understand the complex relationships between distributive and procedural justice, perceived organizational support, and organizational commitment. PLS- based structural equation modeling can be seen as a least square alternative for structural equation modeling (which uses, in general, a maximum likelihood estimation approach), in which this is a recent technique that generalizes and combines features from principal component analysis and multiple regression. Its goal is to predict or analyze a set of dependent variables from a set of independent variables or predictors. This prediction is achieved by extracting from the predictors a set of orthogonal factors called latent variables which have the best predictive power.

\section{Findings}

Confirmatory factor analysis was conducted for each of the latent variables to examine the validity of the measures. The standardized factor loadings are presented in Table I. As depicted in Table I, every factor loading was founded as statistically significant $(p, 0.001)$ and with greater than the recommended value of 0.5 (Fornell and Larcker, 1981).

Descriptive statistics for these independent variables, as well as the intervening and dependent variables in structural model, are presented in table 1.Confirmatory factor analysis results showed statistical evidence (as reported in Table 1) that each component construct of distributive justice, procedural justice, perceived organizational support and organizational commitment are fits the data well. The fit statistics were within generally accepted ranges, indicating that our research model with POS as a higher-order reflective construct (highest average of standardized factor loading compared with other variables). 
INTERNATIONAL JOURNAL OF ACADEMIC RESEARCH IN BUSINESS AND SOCIAL SCIENCES Vol. 8, No. 12, Dec, 2018, E-ISSN: 2222-6990 C 2018 HRMARS

Table 1. Mean, Standard Deviation and Factor Loading

\begin{tabular}{|c|c|c|c|}
\hline & Mean & SD & $\begin{array}{c}\text { Standardized } \\
\text { Factor } \\
\text { Loadings }\end{array}$ \\
\hline \multicolumn{4}{|l|}{ Distributive Justice } \\
\hline Fairly rewarding consider responsibilities & 3.55 & .916 & 0.825 \\
\hline $\begin{array}{l}\text { Fairly rewarding consider account the amount of } \\
\text { education and training }\end{array}$ & 3.67 & .816 & 0.854 \\
\hline Fairly rewarding consider amount of effort & 3.52 & .969 & 0.844 \\
\hline Fairly rewarding consider stresses and strains of job & 3.64 & .932 & 0.862 \\
\hline Fairly rewarding consider work that have been done & 3.71 & 1.043 & 0.846 \\
\hline \multicolumn{4}{|l|}{ Procedural Justice } \\
\hline Consistent of applied procedure & 3.86 & .843 & 0.723 \\
\hline Applied procedure is free of bias & 3.86 & .814 & 0.861 \\
\hline Applied procedure is based on accurate information & 3.76 & .983 & 0.932 \\
\hline $\begin{array}{l}\text { Applied procedure is based on ethical and moral } \\
\text { standards }\end{array}$ & 3.88 & .993 & 0.825 \\
\hline $\begin{array}{l}\text { Appeal the decision arrived at from the performance } \\
\text { appraisal }\end{array}$ & 3.81 & .994 & 0.874 \\
\hline \multicolumn{4}{|l|}{ Perceived Organizational Support } \\
\hline Organization cares about my opinions & 3.43 & 1.039 & 0.898 \\
\hline Organization takes pride in accomplishments & 3.52 & 1.042 & 0.903 \\
\hline Organization values my contribution & 3.76 & 1.144 & 0.918 \\
\hline Organization appreciate any extra effort & 3.71 & 1.019 & 0.864 \\
\hline Organization care about problem & 3.62 & 1.188 & 0.873 \\
\hline Organization really cares about well-being & 3.60 & .767 & 0.713 \\
\hline Organization cares about my opinions & 3.43 & 1.039 & 0.898 \\
\hline \multicolumn{4}{|l|}{ Organizational Commitment } \\
\hline $\begin{array}{l}\text { I do feel a strong sense of belonging to the } \\
\text { organization }\end{array}$ & 3.69 & .86920 & 0.823 \\
\hline $\begin{array}{l}\text { I really feel as if the organization's problems are my } \\
\text { own }\end{array}$ & 3.45 & .86115 & 0.908 \\
\hline I do feel "emotionally attached" to the organization & 3.67 & 1.02806 & 0.848 \\
\hline This organization deserves my loyalty & 3.67 & 1.09693 & 0.865 \\
\hline $\begin{array}{l}\text { I would not leave the organization because I have a } \\
\text { sense of obligation }\end{array}$ & 3.43 & 1.17167 & 0.870 \\
\hline $\begin{array}{l}\text { Even if it were my advantage, I do not feel it would } \\
\text { be right leaving organization }\end{array}$ & 3.47 & .96873 & 0.822 \\
\hline
\end{tabular}


INTERNATIONAL JOURNAL OF ACADEMIC RESEARCH IN BUSINESS AND SOCIAL SCIENCES Vol. 8, No. 12, Dec, 2018, E-ISSN: 2222-6990 @ 2018 HRMARS

\begin{tabular}{|c|c|c|c|}
\hline $\begin{array}{l}\text { Right now, staying with organization is a matter of } \\
\text { necessity }\end{array}$ & 3.47 & 1.08736 & 0.916 \\
\hline $\begin{array}{l}\text { I feel that I have too few options to consider leaving } \\
\text { this organization }\end{array}$ & 3.50 & .86250 & 0.679 \\
\hline $\begin{array}{l}\text { One of the few negative consequences of leaving this } \\
\text { organization would be the scarcity of available } \\
\text { alternatives }\end{array}$ & 3.52 & 1.01784 & 0.756 \\
\hline $\begin{array}{l}\text { I do feel a strong sense of belonging to the } \\
\text { organization }\end{array}$ & 3.69 & .86920 & 0.823 \\
\hline
\end{tabular}

Table 2 showed descriptive statistics, scale reliability, and zero-order correlations between the variables. The average variance extracted (AVE) for the constructs of distributive justice, procedural justice, perceive organizational support, and organizational commitment were 0.716, 0.715, 0.747, and 0.697, respectively. While the high composite reliabilities among variables were 0.926, 0.925, 0.946, and 0.953, respectively. The reliability coefficients were consistent with the literature and higher than the 0.70 threshold. Composite reliability and AVE can be assessed to confirm discrimination and convergent validity among constructs in study. To further test for discriminant validity, the AVE for each factor was compared with and exceeded the squared correlations between that factor and all other factors (see Table 2).

Table 2. Descriptive Statistic, Intercorrelations and PLS Quality Criteria

\begin{tabular}{lcccc}
\hline & 1 & 2 & 3 & 4 \\
\hline 1.Distributive Justice & $(.901)$ & & & \\
2.Procedural Justice & $.808^{* *}$ & $(.898)$ & & \\
3.Perceived Organizational Support & $.743^{* *}$ & $.727^{* *}$ & $(.931)$ & \\
4.Organizational Commitment & $.700^{* *}$ & $.691^{* *}$ & $.890^{* *}$ & $(.945)$ \\
Mean & 3.619 & 3.833 & 3.607 & 3.542 \\
Standard Deviation & 3.956 & 3.913 & 5.391 & 7.490 \\
AVE & .716 & .715 & .747 & .697 \\
Composite Reliability & .926 & .925 & .946 & .953 \\
\hline
\end{tabular}

Notes: ${ }^{* *} p, 0.01 ; * p, 0.05 ;$ Cronbach's alphas for each scale are italicised and shown in the diagonal.

All correlations were significant. An overview suggests that data were consistent with previous studies. Distributive justice was positively related to procedural justice $(r=0.808, p, 0.01)$, POS $(r=$ $0.743, p, 0.01)$, and organizational commitment $(r=0.700, p, 0.01)$. Procedural justice was positively related to POS ( $r=0.727, p, 0.01)$, and organizational commitment $(r=0.691, p, 0.01)$. In addition, POS was found to be positively related to commitment $(r=0.890, p, 0.01)$.

In order to test the hypotheses, a structural model was estimated with four constructs: distributive justice, procedural justice, perceived organizational support, and organizational commitment. In the model, all of organizational (distributive and procedural) justice are exogenous 
INTERNATIONAL JOURNAL OF ACADEMIC RESEARCH IN BUSINESS AND SOCIAL SCIENCES Vol. 8, No. 12, Dec, 2018, E-ISSN: 2222-6990 @ 2018 HRMARS

constructs, while perceived organizational support and organizational commitment are endogenous constructs.

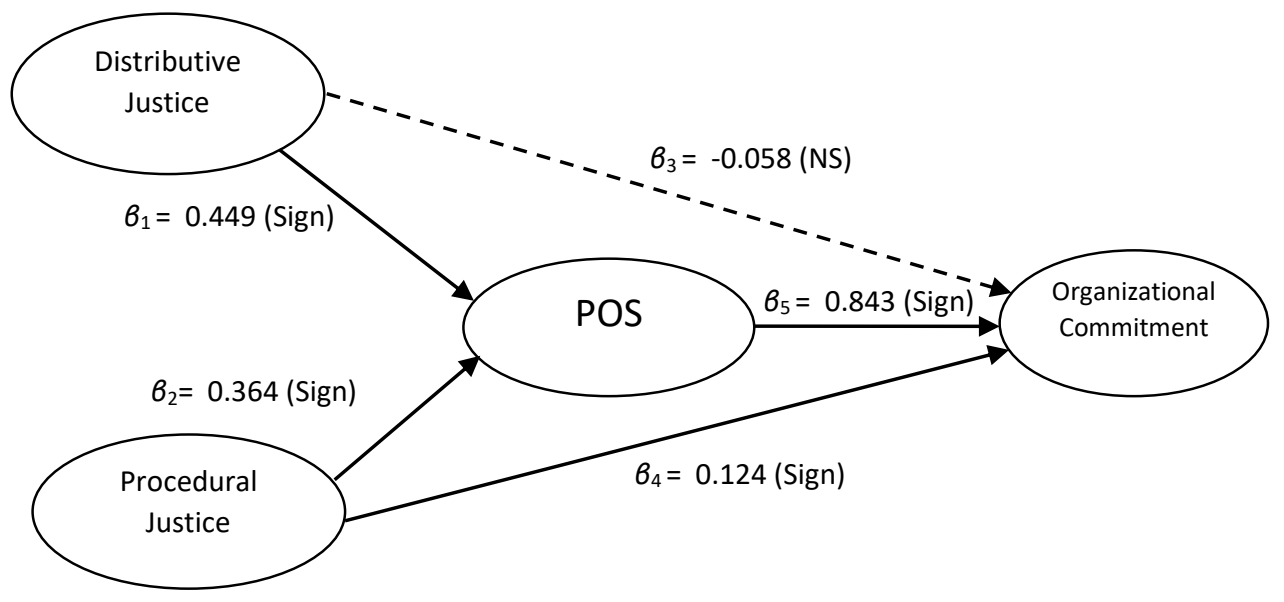

Figure 2.Path Analysis

Figure 2 displayed the result of the analysis of model proposed in this study. Standardized parameter estimates for the model are presented. The results indicated that the first hypothesis was supported. Public officers' perceptions of distributive justice had a significant positive relationship with perceived organizational support. As indicated by the path coefficient, the relationship between distributive justice and perceived organizational support was relatively moderate, $0.449(p<0.01)$. Second hypothesis was also supported, it was shown that public officers' perceptions of procedural justice had a significant positive relationship with perceived organizational support by moderate coefficient of $0.364(p<0.01)$.

Figure 2 plots the levels of distributive and procedural justice to organizational commitment. In contrast, no support was found for Hypothesis 3, i.e. there was no evidence of a significant relationship between distributive justice and organizational commitment $(B=-0.058, p>0.05)$. A greater distributive justice would not affect organizational commitment significantly among public officers. It illustrates that the path in linear model of justice towards commitment has different result. A weak positive relationship was established between procedural justice and organizational commitment $(\beta=0.124, p<0.05)$. Finding reveals a predicted level of procedural justice will significantly increase public officers' commitment.

In testing hypotheses 5 , the addition of POS was associated with organizational commitment. Perceived organizational support had a significant positive effect on organizational commitment ( 6 $=0.843, p<0.01)$. Therefore, the results showed that hypothesis 5 was supported. It is clear from the diagram (Figure 2) that the effects of POS on commitment is founded as the greatest effect in the relationship between two variables compared with other effects in the model. This means POS has a very important role in fostering public officers' organizational commitment.

To test the mediating effects of perceived organizational support on the relationship between distributive and procedural justice on organizational commitment (Hypotheses 6 and7), two models 
were examined, a full and a partial mediation model. Model 1, a full mediation model, included path from distributive justice to the POS and from the POS to organizational commitment. Model 2, a partial mediation model, was identical to model 1 with the exception that direct paths were included from procedural justice to organizational commitment. As for the model which tested in this study confirms that perceived organizational support have important mediating role in the relationship of distributive and procedural justice on organizational commitment. The result showed that the hypothesis 6 and 7 were supported, meaning that perceived organizational support more strongly mediates the impact of justice on commitment.

\section{Conclusion}

The overall results of the study give strong support to our entire hypotheses, except for one hypothesis that is rejected. It was successfully found out that there was a significant impact of distributive and procedural justice on perceived organizational support, and thus perceived organizational support on organizational commitment. The more involvement of this research is that perceived organizational support importantly mediate the relationship between distributive and procedural justice on organizational commitment.

From findings reveal that the present study supports and extends existing social exchange literature by ratifying distributive and procedural justice as a significant predictor of perceptions of organizational support. But in contrary, public officers notice that distributive justice could not directly affect their commitment to organization. This is based on result that show one hypothesis is rejected, that is relationship of distributive justice and organizational commitment. It implies to public managers and supervisors may take not only suitable steps to ensure distributive justice through fair work norms and compensation, but also how to foster employee's feeling to be supported by organization. In addition, this finding stresses the usefulness of obtaining high POS among public officers, in which results further imply that public organizational treatment has implications for the nature of employee-employer psychological contracts.

Consistent with Cropanzano and Mitchell (2005) results in explaining the relationship of exchange something that must be given is always related with something must be returned, the result of this study indicated that POS (as viewed the gift) will foster desirable work outcome specifically to organizational commitment. These findings is expected to imply in commitment literature in public management which suggests that perceived organizational support perhaps particularly influential on employee commitment to organization because being supported by organization will led to fostering greater attachment and loyalty to organization.

When the supervisors or managers (in public organization) takes initiatives which are aimed at taking care of and concern about public officers' well-being, in return, the willingness among public officers to be more loyal and attached with organization for the benefit of the employer increases. An interesting, a surprising, finding of this study suggests that distributive justice does not account for, or explain, commitment to the organization. Practically, this will imply on a leader or administrator in public organization which should not expect to improve employee levels of organizational commitment by focusing on distributive justice. This presents an interesting finding and that more research would be needed to better understand the issue before making any final conclusions. 
The contribution of this article has been to shed light on the relationship among organizational justice, support, and commitment. This study analyzed whether distributive and procedural justice can be utilized in the Indonesian public sector to engender higher levels of public officers' commitment and generate a better understanding of the social exchange mechanisms by which perceived organizational support exerts its influence on organizational commitment.

Aside from these theoretical contributions, the results have some practical implications. In the context of the public sector in Indonesia, it is to improve organizational effectiveness through organizational commitment. Understanding how organizational commitment can be enhanced through perceived organizational support is particularly important, given the limited success that fairness programs in public organization in Indonesia in the past to increase commitment among civil servants. Having more committed subordinates who feel supported by organization is essential for public organizations. Also, future work could be pursued that focuses on these linkages and investigates the exchange between leaders and their subordinates.

This study has some limitations. First, the use of cross-sectional data will lead to result that is not able to address the causality of the relationships hypothesized, because such a research design does not allow for an examination of long-term effects. Researchers can address these limitations in the future by collecting longitudinal data with an experimental design. Second, another limitation is concerned with the nature of the sample in public sector in West Java Government Office in Indonesia. Thus, any generalization of findings in this study to other groups or organizations outside the sample should be considered cautiously. Third, the use of self-reported measures raises concerns regarding the possibility that the respondents might have provided socially desirable responses. In this regard, future research should also consider other types of organizations or use multiple sources to verify the findings of this study.

\section{Acknowledgment}

This paper is a revised and expanded version of a paper entitled Organisational Justice, Support, and Commitment among Civil Servant Officer in Public Organisation presented at The 1st International Conference on Governance, Public Administration, and Social Sciences (ICoGPASS), Grand Inna Malioboro Hotel Yogyakarta, July 19th, 2018. The authors would like to express their gratitude to all participants who took part in this study and the three anonymous reviewers for their suggestions during the development of this article.

\section{Corresponding Author}

\section{Hafid Aditya Pradesa}

Lecturer, Corresponding Author.

Email: hafidap85@gmail.com

School of Administration, National Agency for State Administration, Bandung, West Java, Indonesia

\section{References}

Allen, N.J. \& Meyer, J.P. (1990).The measurement and antecedents of affective, continuance and normative commitment to the organization. Journal of Occupational Psychology, 63(1), 1-18. 
INTERNATIONAL JOURNAL OF ACADEMIC RESEARCH IN BUSINESS AND SOCIAL SCIENCES

Vol. 8, No. 12, Dec, 2018, E-ISSN: 2222-6990 @ 2018 HRMARS

Aselage, J. , \& Eisenberger, R. (2003). Perceived organizational support and psychological contracts: A theoretical integration. Journal of Organizational Behavior, 24, 491-509.

Boyne, G., Poole, M., and Jenkins, G. (1999).Human Resource Management in the Public and Private Sectors: An Empirical Comparison. Public Administration, 77, 2, 407-420.

Clay-Warner, J., Reynolds, J. and Roman, P. (2005).Organizational justice and job satisfaction: a test of three competing models. Social Justice Research, Vol. 18, pp. 391-409.

Chou, R.J.A. (2009).Organizational justice and turnover intention: a study of direct care workers in assisted living facilities for older adults in the United States. Social Development Issues, Vol. 31, pp. 69-85.

Colquitt, J.A. (2001).On the dimensionality of organizational justice: a construct validation of a measure. Journal of Applied Psychology, Vol. 86, pp. 386-400.

Colquitt, J.A., Conlon, D.E., Wesson, M.J., Porter, C.O.L.H. and Ng, K.Y. (2001).Justice at the millennium: a meta-analytic review of 25 years of organizational justice research.Journal of Applied Psychology, Vol. 86, pp. 425-45.

Crawshaw, J. R.(2006).Justice source and justice content: Evaluating the fairness of organisational career management practices.Human Resource Management Journal, Vol. 16 No. 1, pp. 98120.

Cropanzano, R. and Greenberg, J. (1997).Progress in organizational justice: tunneling through the maze, in Cooper, C.L. and Robertson, I.T. (Eds), International Review of Industrial and Organizational Psychology, Wiley, New York, NY, pp. 317-72.

Cropanzano, R., and Mitchell, M. (2005).Social Exchange Theory: An Interdisciplinary Review. Journal of Management, 31, 6, 874-899.

Crow, M.S., Lee, C.B., Joo, J.J. (2012).Organizational justice and organizational commitment among South Korean police officers : An investigation of job satisfaction as a mediator. Policing: An International Journal of Police Strategies \& Management, Vol. 35 No. 2, 2012 pp. 402-423. DOI 10.1108/13639511211230156.

Currie, P. and Dollery, B. (2006).Organizational commitment and perceived organizational support in the NSW police. Policing: An International Journal of Police Strategies \& Management, Vol. 29, pp. 741-56.

Dick, G.P.M. (2011).The Influence of Managerial and Job Variables on Organizational Commitment in the Police. Public Administration, 89, 2, 557-76.

Eisenberger, R., Fasolo, P., and Davis-LaMastro, V. (1990).Perceived Organizational Support and Employee Diligence, Commitment, and Innovation. Journal of Applied Psychology, 75, 1, 5159.

Eisenberger, R., Huntington, R., Hutchison, S., and Sowa, D. (1986). Perceived Organizational Support. Journal of Applied Psychology, 71, 500-507.

Fornell, C. and Larcker, D.F. (1981). Evaluating structural equation models with unobservable variables and measurement error. Journal of Marketing Research, Vol. 18, pp. 39-50.

Johnson, Richard R. (2015).Police Organizational Commitment: The Influence of Supervisor Feedback and Support. Crime \& Delinquency, Vol. 61(9) 1155-1180.

Jones, F. (1998).Pay procedures and voluntary turnover: does procedural justice matter?. Psychological Reports, Vol. 83, pp. 475-82. 
INTERNATIONAL JOURNAL OF ACADEMIC RESEARCH IN BUSINESS AND SOCIAL SCIENCES Vol. 8, No. 12, Dec, 2018, E-ISSN: 2222-6990 @ 2018 HRMARS

Kim, H. (2014). Transformational Leadership, Organizational Clan Culture, Organizational Affective Commitment, and Organizational Citizenship Behavior: A Case of South Korea's Public Sector. Public Organization Review, Vol. 14, Issue 3, pp.397-417. DOI: 10.1007/s11115-013-0225-z.

Kwong, J.Y., Leung, K.(2002).A moderator of the interaction effect of procedural justice and outcome favourability: importance of the relationship.Organizational Behavior and Human Decision Processes, Vol. 87, pp. 278-300.

Lambert, E., Hogan, N.L. and Griffin, M.L. (2007).The impact of distributive and procedural justice on correctional staff job stress, job satisfaction, and organizational commitment.Journal of Criminal Justice, Vol. 35, pp. 644-56.

Miao, Q., Newman, A., Schwarz, G., and Xu, L.(2014). Servant Leadership, Trust, and The Organizational Commitment of Public Sector Employees in China. Public Administration Vol. 92, No. 3, 2014 (727-743). DOI: 10.1111/padm.12091.

Moldogaziev, T.T., Silvia, C.(2015).Fostering Affective Organizational Commitment in Public Sector Agencies : The Significance of Multifaceted Leadership Roles. Public Administration Vol. 93, No. 3, 2015 (557-575). DOI: 10.1111/padm.12139.

Muchinsky, P.M. (2008).Psychology Applied to Work: An Introduction to Industrial and Organizational Psychology.Hypergraphic Press, Summerfield, NC.

Niehoff, B. P., \& Moorman, R. H. (1993).Justice As a Mediator Of The Relationship Between Methods Of Monitoring and Organizational Citizenship Behavior. Academy of Managemet Journal, Vol.36. No.3. 527-556.

Paillé, Pascal; Grima, Francois; Dufour, Marie-Ève. (2015). Contribution to social exchange in public organizations: examining how support, trust, satisfaction, commitment and work outcomes are related.The International Journal of Human Resource Management, Volume 26, 2015 Issue 4. DOI: 10.1080/09585192.2012.654809.

Rhoades, L., and Eisenberger, R. (2002). Perceived Organizational Support : A Review of the Literature. Journal of Applied Psychology, Vol 87, No. 4, 698- 714.

Shore, L. M., \& Shore, T. H. (1995).Perceived organizational support and organizational justice. Academy of Management Journal, 40(1), 82-111.

Steijn, B. and P. Leisink.(2006). Organizational Commitment among Dutch Public Sector Employees. International Review of Administrative Sciences, 72, 2, 187-201.

Zhou, Y., Mao, Q. (2014).Servant Leadership and Affective Commitment in The Chinese Public Sector : The Mediating Role of Perceived Organizational Support. Psychological Reports: Employment Psychology \& Marketing, 2014, 115, 2, 381-395. 